Selcuk Journal of Agriculture and Food Sciences

$\underline{\text { http://sjafs.selcuk.edu.tr/sjafs/index }}$

Research Article
SJAFS

(2021) $35(1), 1-11$

e-ISSN: $2458-8377$

DOI:10.15316/SJAFS.2020.221

\title{
Determination of Natural Risk Sources Effective in Wheat Production in Hadim District with the Help of Linear Programming
}

\author{
Yasin ALTAY $^{1 *}$, (D) İsmail KESKIN ${ }^{2}$
}

${ }^{1}$ Eskisehir Osmangazi University, Faculty of Agriculture, Department of Animal Science, Eskişehir, Turkey

${ }^{2}$ Selcuk University, Faculty of Agriculture, Department of Animal Science, Konya, Turkey

\begin{tabular}{l}
\hline ARTICLE INFO \\
\hline Article history: \\
Received date: 10.09 .2020 \\
Accepted date: 11.10 .2020 \\
\hline $\begin{array}{l}\text { Edited by: } \\
\text { İbrahim AYTEKIN; Selcuk University, } \\
\text { Turkey }\end{array}$ \\
\hline
\end{tabular}

Keywords:

Risk Analysis

Wheat

Linear programming

Simplex algorithm

Hadim

\begin{abstract}
There are many sources of natural risks affecting wheat cultivation. In this study, it is aimed to estimate the minimum and maximum risk ranges and premium and compensation amounts of the natural risk factors affecting the wheat yield in Hadim district of Konya in terms of farmers and insurance.As natural risk factors, disease and pests, frost, drought, hail, fire and the interactions of other risks and factors were examined.The number of factors dealt with in the study is 6 , and the total number of linear models created using all combinations is 63.The 63 linear models established, the minimum and maximum risk ranges in terms of farmers and insurance were determined by using the simplex method of linear programming on the basis of yield and price.In addition, diseases and pests and other risk factors not included in the scope of agricultural insurances were included in the linear models and wheat yield was estimated on district basis.In the model with all risk factors, the expected risk value of the farmer is 64.962 (kg / ha-1) -71.588 (TL / ha-1), while it is estimated as 53.548 ( $\mathrm{kg} / \mathrm{ha}-1)-59.009$ (TL / ha-1) in terms of insurance. has been. As a result, it was estimated that the farmer paid 20,831 (TL / ha-1) premiums and 122,344 (TL / ha-1), while insurance companies paid 59,009 (TL / ha-1) premium 84,018 (TL / ha-1) compensation.
\end{abstract}

\section{Introduction}

Agricultural products are under great risk with the increase of global warming and natural disasters in the world. Although there are many factors that affect yield in agricultural products, the biggest share belongs to natural risk factors. Natural risk factors are common from diseases and pests, frost, drought, hail, fire, earthquake, storm, tornado, landslide, flood and other risks. While it is almost impossible to control climaticinduced natural risk factors, it is partially possible to detect them with the help of early warning systems thanks to developing technology. These events, which occur outside the control of the growers, cause fluctuations in the production of agricultural products. These fluctuations in yield cause the farmers to worry economically (Akçaöz, 2006).

The geographical location of both Turkey and also to take part in many climates although it is quite conducive to a variety of agricultural production, the

\footnotetext{
*Corresponding author email: yaltay@ogu.edu.tr
}

sector is experiencing a troubled period in terms of economy due to reasons such as the lack of efficient production unions, competition among agricultural product exchanges, low education level, rural to urban migration, climate change, deterioration of ecological balance, disasters and disasters.This situation negatively affects both the income of the producer and the national economy (Karaca et al., 2010; Tsikirayi et al., 2013; Cangi \& Oruç, 2017).

The main natural risk factors in wheat production are diseases and pests, frost, drought, hail, fire, etc. It is known that it causes significant loss of yield and low quality as a result of not taking into account the risk factors determined during production (Altay, 2019).

Irregular yields of agricultural products pushed producers to seek assurance to continue their activities (Çukur \& Saner, 2008; İkikat Tümer, 2011a; İkikat Tümer, 2011b; Karahan Uysal et al., 2014; Terin \& Aksoy, 2015; Tümer, 2019).It has become inevitable that agricultural products produced under risk are covered by insurance and partially compensated for 
the losses incurred.One of the ways to overcome these various and common risks in the agricultural sector is agricultural insurance (Binici et al., 2003; İkikat Tümer, 2004).In this context, after previously functioning of private insurance companies in Turkey rose Law Agricultural Insurance in 2005.Agricultural Insurance Pool and TARSIM started their activities in 2006 (Sümer \& Polat, 2016).In this context, the development of agricultural policies within the scope of agricultural insurance in recent years is a beacon of hope for our country's producers.

Turkey continues its activities by state agricultural insurance and negotiated private insurance companies. Both premium and policy support are provided to farmers from the agricultural insurance pool fund. In herbal product insurances, $50 \%$ of insurance premiums, $66.67 \%$ of frost coverage and $60 \%$ of district-based drought have been secured by the state for free (Ertan \& Gök, 2012; Kızıloğlu, 2017; Anonymous, 2019).

In this study, it is aimed to estimate the minimum and maximum risk ranges and premium and indemnity amounts in terms of farmers and insurance by making risk analysis of natural risk factors that are effective in wheat production in Hadim district.

\section{Materials and Methods}

Hadim district, located in the south of Konya, is located on the Taşeli Plateau between $36^{\circ} 59$ 'north latitude and $32^{\circ} 27^{\prime}$ east longitude (Figure 1). The average altitude above sea level is $1510 \mathrm{~m}$, the annual average rainfall is $619 \mathrm{~mm}$ and the surface area is 921 $\mathrm{km}^{2}$. Situated on a valley in the Central Taurus Mountains, Hadim is located in the Mediterranean region and does not fully show the characteristic features of the Mediterranean climate (Anonymous, 2018).In this respect, it shows a transition feature between Terrestrial climate and Mediterranean climate (Anonymous, 2018).It receives more precipitation than the terrestrial climate and is among the districts with the highest day and night temperature difference.Mostly grown field products in Hadim are wheat, barley and chickpeas. Among these products, the product with the most growing area is wheat with $60.82 \%$, and the average wheat yield in the district is 280 kg / da (Anony-mous, 2018; Tuik, 2018; Anonymous, 2018a).

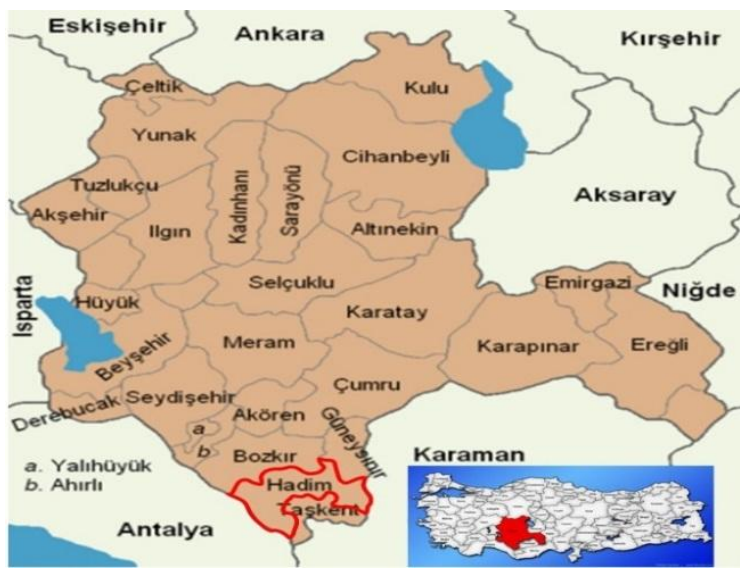

Figure 1

Konya province Hadim district map (Anonim, 2018a).

The probability, frequency and corrected probability values of the natural risk factors and interactions examined in the wheat production of $\mathrm{Ha}-$ dim district were determined by the experts in the light of meteorological data. The probability values of interactions were inspired by the probability of occurring two or more events at the same time and were calculated as $\mathrm{P}$ (A) $\mathrm{xP}$ (B) $\mathrm{x} \ldots$ xP (n).In determining the risk frequencies of interactions, the average of the related main risk factors was taken (Table 1).The effects of natural risk factors and interactions examined in the wheat production of $\mathrm{Ha}-$ dim district were evaluated by local farmers, agricultural engineers and faculty members in the light of various literature and determined by brainstorming (Table 2).

Risk analysis consists of two basic components, risk realization probability and risk effect, and it is calculated as Risk $=(\mathrm{RGO} \times \mathrm{RF}) \times \mathrm{RGE}$ (Erdoğan, 2017).In wheat production, the period of the plant when the risk occurs will change the severity of the risk effect. Therefore, while calculating the risk in wheat production, without ignoring the effect of time (it takes values between 0-3), the frequency of the risk should also be included in the calculation. Taking the frequencies of the risk as the coefficient of the constraints helped to calculate the weighted average of the risks in terms of time.Finally, risk calculation takes the form of Risk = DRO x RGE (RGO: Probability of Risk Realization, RF: Frequency of Risk, RGE: Effect of Risk on Occurrence, DRO: Probability of Adjusted Risk). The formation stages of linear programming were carried out with the following mathematical expressions (Apaydın, 1996; Sucu, 1996; Yapıc1, 2000). The creation of the objective function has been designed and applied in the logic of a multi-factor linear model that varies according to the number of factors.

Objective function;

$\operatorname{Max}(\operatorname{Min}) \mathrm{Z}(\mathrm{x})=\mathrm{CX}$

Constraints; $\mathrm{AX}\{\leq,=, \geq\}$ B 
Altay and Keskin / Selcuk J Agr Food Sci, (2021) 35 (1), 1-11

Table 1

Frequencies and Probability of Natural Risks Which are Taken in Wheat Production of Hadim District, Konya

\begin{tabular}{|c|c|c|c|c|c|c|c|}
\hline \multirow[b]{2}{*}{ Natural Risks } & \multirow[b]{2}{*}{ Symbols } & \multicolumn{2}{|c|}{ Risk Probability } & \multicolumn{2}{|c|}{ Risk Frequency } & \multicolumn{2}{|c|}{ Adjusted Risk Probability } \\
\hline & & Min & Max & Min & $\operatorname{Max}$ & Min & Max \\
\hline Diseases and Pests & $\mathrm{x} 1$ & 0.10 & 0.20 & 1.250 & 2.200 & 0.125 & 0.44 \\
\hline Frost & $\mathrm{x} 2$ & 0.15 & 0.25 & 1.250 & 1.950 & 0.1875 & 0.4875 \\
\hline Drought & $\mathrm{x} 3$ & 0.05 & 0.25 & 1.200 & 2.050 & 0.06 & 0.5125 \\
\hline Hail & $\mathrm{x} 4$ & 0.03 & 0.08 & 1.150 & 1.500 & 0.0345 & 0.12 \\
\hline Fire & $\mathrm{x} 5$ & 0.001 & 0.003 & 1.030 & 1.070 & 0.00103 & 0.00321 \\
\hline Others & $\mathrm{x} 6$ & 0.15 & 0.25 & 1.300 & 2.350 & 0.195 & 0.5875 \\
\hline Diseases and Pests- Frost & $\mathrm{x} 12$ & 0.015 & 0.05 & 1.250 & 2.075 & 0.01875 & 0.10375 \\
\hline Diseases and Pests- Drought & $\mathrm{x} 13$ & 0.005 & 0.05 & 1.225 & 2.125 & 0.006125 & 0.10625 \\
\hline Diseases and Pests- Hail & $\mathrm{x} 14$ & 0.003 & 0.016 & 1.200 & 1.850 & 0.0036 & 0.0296 \\
\hline Diseases and Pests- Fire & $\mathrm{x} 15$ & 0.0001 & 0.0006 & 1.140 & 1.635 & 0.000114 & 0.000981 \\
\hline Diseases and Pests- Others & $\mathrm{x} 16$ & 0.015 & 0.05 & 1.275 & 2.275 & 0.019125 & 0.11375 \\
\hline Frost- Drought & $\mathrm{x} 23$ & 0.0075 & 0.0625 & 1.225 & 2.000 & 0.0091875 & 0.125 \\
\hline Frost- Hail & $\mathrm{x} 24$ & 0.0045 & 0.02 & 1.200 & 1.725 & 0.0054 & 0.0345 \\
\hline Frost- Fire & $\mathrm{x} 25$ & 0.00015 & 0.00075 & 1.140 & 1.510 & 0.000171 & 0.0011325 \\
\hline Frost- Others & $\mathrm{x} 26$ & 0.0225 & 0.0625 & 1.275 & 2.150 & 0.0286875 & 0.134375 \\
\hline Drought- Hail & x34 & 0.0015 & 0.02 & 1.175 & 1.775 & 0.0017625 & 0.0355 \\
\hline Drought- Fire & $\mathrm{x} 35$ & 0.00005 & 0.00075 & 1.115 & 1.560 & 0.00005575 & 0.00117 \\
\hline Drought- Others & $\mathrm{x} 36$ & 0.0075 & 0.0625 & 1.250 & 2.200 & 0.009375 & 0.1375 \\
\hline Hail- Fire & $\mathrm{x} 45$ & 0.00003 & 0.00024 & 1.090 & 1.285 & 0.0000327 & 0.0003084 \\
\hline Hail- Others & $\mathrm{x} 46$ & 0.0045 & 0.02 & 1.225 & 1.925 & 0.0055125 & 0.0385 \\
\hline Fire - Others & $\mathrm{x} 56$ & 0.00015 & 0.00075 & 1.165 & 1.710 & 0.00017475 & 0.0012825 \\
\hline Diseases and Pests- Frost- Drought & $\mathrm{x} 123$ & 0.00075 & 0.0125 & 1.233 & 2.067 & 0.000925 & 0.0258333 \\
\hline Diseases and Pests- Frost- Hail & x124 & 0.00045 & 0.004 & 1.217 & 1.883 & 0.0005475 & 0.0075333 \\
\hline Diseases and Pests- Frost- Fire & x125 & 0.000015 & 0.00015 & 1.177 & 1.740 & 0.00001765 & 0.000261 \\
\hline Diseases and Pests- Frost- Others & x126 & 0.00225 & 0.0125 & 1.267 & 2.167 & 0.00285 & 0.0270833 \\
\hline Diseases and Pests- Drought- Hail & x134 & 0.00015 & 0.004 & 1.200 & 1.917 & 0.00018 & 0.0076667 \\
\hline Diseases and Pests- Drought- Fire & x135 & 0.000005 & 0.00015 & 1.160 & 1.773 & 0.0000058 & 0.000266 \\
\hline Diseases and Pests- Drought- Others & x136 & 0.00075 & 0.0125 & 1.250 & 2.200 & 0.0009375 & 0.0275 \\
\hline Diseases and Pests- Hail- Fire & x145 & 0.000003 & 0.00005 & 1.143 & 1.590 & 0.00000343 & 0.00007950 \\
\hline Diseases and Pests- Hail- Others & x146 & 0.00045 & 0.004 & 1.233 & 2.017 & 0.000555 & 0.0080667 \\
\hline Diseases and Pests- Fire- Others & $\mathrm{x} 156$ & 0.000015 & 0.00015 & 1.193 & 1.873 & 0.0000179 & 0.000281 \\
\hline Frost- Drought- Hail & $\mathrm{x} 234$ & 0.000225 & 0.005 & 1.200 & 1.833 & 0.00027 & 0.0091667 \\
\hline Frost- Drought- Fire & $\mathrm{x} 235$ & 0.0000075 & 0.000188 & 1.160 & 1.690 & 0.0000087 & 0.0003177 \\
\hline Frost- Drought- Others & x236 & 0.001125 & 0.015625 & 1.250 & 2.117 & 0.00140625 & 0.0330729 \\
\hline Frost-- Hail- Fire & $\mathrm{x} 245$ & 0.0000045 & 0.00006 & 1.143 & 1.507 & 0.000005145 & 0.0000904 \\
\hline Frost- Hail- Others & $\mathrm{x} 246$ & 0.000675 & 0.005 & 1.233 & 1.933 & 0.0008325 & 0.0096667 \\
\hline Frost- Fire- Others & $\mathrm{x} 256$ & 0.0000225 & 0.000188 & 1.193 & 1.790 & 0.00002685 & 0.0003365 \\
\hline Drought- Hail- Fire & x345 & 0.0000015 & 0.00006 & 1.127 & 1.540 & 0.00000169 & 0.00009240 \\
\hline Drought- Hail- Others & x346 & 0.000225 & 0.005 & 1.217 & 1.967 & 0.00027375 & 0.0098333 \\
\hline Drought- Fire- Others & x356 & 0.0000075 & 0.000188 & 1.177 & 1.823 & 0.000008825 & 0.0003428 \\
\hline Hail- Fire- Others & $\mathrm{x} 456$ & 0.0000045 & 0.00006 & 1.160 & 1.640 & 0.00000522 & 0.00009840 \\
\hline Diseases and Pests- Frost- Drought- Hail & x1234 & 0.0000225 & 0.001 & 1.213 & 1.925 & 0.00002728 & 0.001925 \\
\hline Diseases and Pests- Frost- Drought- Fire & x1235 & 0.00000075 & 0.000038 & 1.183 & 1.818 & 0.00000089 & 0.00006907 \\
\hline Diseases and Pests- Frost- Drought- Others & $\mathrm{x} 1236$ & 0.0001125 & 0.003125 & 1.250 & 2.138 & 0.000140625 & 0.0066797 \\
\hline Diseases and Pests- Frost- Hail- Fire & $\mathrm{x} 1245$ & 0.00000045 & 0.000012 & 1.170 & 1.680 & 0.00000053 & 0.00002016 \\
\hline Diseases and Pests- Frost- Hail- Others & $\mathrm{x} 1246$ & 0.0000675 & 0.001 & 1.238 & 2.000 & 0.00008353 & 0.002 \\
\hline Diseases and Pests- Frost- Fire- Others & $\mathrm{x} 1256$ & 0.000002 & 0.00004 & 1.208 & 1.893 & 0.000002415 & 0.00007570 \\
\hline Diseases and Pests- Drought- Hail- Fire & x1345 & 0.00000015 & 0.00001 & 1.158 & 1.705 & 0.00000017 & 0.00001705 \\
\hline Diseases and Pests- Drought- Hail- Others & $\mathrm{x} 1346$ & 0.0000225 & 0.001 & 1.633 & 2.700 & 0.00003675 & 0.0027 \\
\hline Diseases and Pests- Drought- Fire- Others & $\mathrm{x} 1356$ & 0.00000075 & 0.00004 & 1.195 & 1.918 & 0.00000090 & 0.00007670 \\
\hline Diseases and Pests- Hail- Fire- Others & x1456 & 0.00000045 & 0.000012 & 1.183 & 1.780 & 0.00000053 & 0.00002136 \\
\hline Frost- Drought- Hail- Fire & x2345 & 0.000000225 & 0.000015 & 1.158 & 1.643 & 0.00000026 & 0.00002464 \\
\hline Frost- Drought- Hail- Others & x2346 & 0.00003375 & 0.00125 & 1.225 & 1.963 & 0.00004134 & 0.0024531 \\
\hline Frost- Drought- Fire- Others & x2356 & 0.0000011 & 0.000047 & 1.195 & 1.855 & 0.00000131 & 0.00008719 \\
\hline Frost- Hail- Fire- Others & x2456 & 0.0000007 & 0.000015 & 1.183 & 1.718 & 0.00000083 & 0.00002576 \\
\hline Drought- Hail- Fire- Others & x3456 & 0.000000225 & 0.000015 & 1.170 & 1.743 & 0.00000026 & 0.00002614 \\
\hline Diseases and Pests- Frost- Drought- Hail-Fire & $\mathrm{x} 12345$ & 0.000000023 & 0.000003 & 1.176 & 1.754 & 0.00000003 & 0.00000526 \\
\hline Diseases and Pests- Frost- Drought- Hail- Others & x12346 & 0.000003 & 0.00025 & 1.230 & 2.010 & 0.00000369 & 0.0005025 \\
\hline Diseases and Pests- Frost- Drought- Fire- Others & x12356 & 0.0000001 & 0.000009 & 1.206 & 1.924 & 0.00000012 & 0.00001732 \\
\hline Diseases and Pests- Frost- Hail- Fire- Others & x12456 & 0.00000007 & 0.0000030 & 1.196 & 1.814 & 0.00000008 & 0.00000544 \\
\hline Diseases and Pests- Drought- Hail-Fire- Others & x13456 & 0.000000023 & 0.000003 & 1.186 & 1.834 & 0.00000003 & 0.00000550 \\
\hline Frost- Drought- Hail-Fire- Others & x23456 & 0.000000034 & 0.000004 & 1.186 & 1.784 & 0.00000004 & 0.00000714 \\
\hline Diseases and Pests-Frost- Drought-Hail-Fire-Others & $\mathrm{x} 123456$ & 0.0000000034 & 0.0000008 & 1.197 & 1.853 & 0.000000004 & 0.00000148 \\
\hline
\end{tabular}


Altay and Keskin / Selcuk J Agr Food Sci, (2021) 35 (1), 1-11

Table 2

Effect of Natural Risks Which are Taken in Wheat Production of Hadim District, Konya

\begin{tabular}{|c|c|c|c|c|c|}
\hline \multirow{2}{*}{ Natural Risks } & \multirow{2}{*}{ Symbols } & \multicolumn{2}{|c|}{$\begin{array}{l}\text { Effect of Risks for Farmer } \\
\left(\mathrm{kg} / \mathrm{ha}^{-1}\right)\end{array}$} & \multicolumn{2}{|c|}{$\begin{array}{l}\text { Effect of Risks for Insurance } \\
\qquad\left(\mathrm{kg} / \mathrm{ha}^{-1}\right)\end{array}$} \\
\hline & & Min & Max & Min & $\operatorname{Max}$ \\
\hline Diseases and Pests & $\mathrm{x} 1$ & 45 & 120 & 0 & 0 \\
\hline Frost & $\mathrm{x} 2$ & 25 & 115 & 40 & 65 \\
\hline Drought & $\mathrm{x} 3$ & 20 & 75 & 40 & 45 \\
\hline Hail & $\mathrm{x} 4$ & 20 & 130 & 30 & 70 \\
\hline Fire & $\times 5$ & 10 & 280 & 20 & 200 \\
\hline Others & x6 & 35 & 145 & 80 & 100 \\
\hline Diseases and Pests- Frost & $\mathrm{x} 12$ & 30 & 155 & 60 & 100 \\
\hline Diseases and Pests- Drought & $\mathrm{x} 13$ & 35 & 135 & 55 & 85 \\
\hline Diseases and Pests- Hail & $\mathrm{x} 14$ & 40 & 180 & 60 & 110 \\
\hline Diseases and Pests- Fire & $\mathrm{x} 15$ & 35 & 280 & 55 & 200 \\
\hline Diseases and Pests- Others & $\mathrm{x} 16$ & 60 & 190 & 95 & 120 \\
\hline Frost- Drought & $\mathrm{x} 23$ & 35 & 130 & 65 & 85 \\
\hline Frost- Hail & $\mathrm{x} 24$ & 35 & 145 & 55 & 90 \\
\hline Frost- Fire & $\mathrm{x} 25$ & 30 & 280 & 45 & 200 \\
\hline Frost- Others & $x 26$ & 55 & 155 & 85 & 95 \\
\hline Drought- Hail & x34 & 35 & 140 & 55 & 85 \\
\hline Drought- Fire & $\mathrm{x} 35$ & 30 & 280 & 45 & 200 \\
\hline Drought- Others & $\mathrm{x} 36$ & 65 & 155 & 95 & 95 \\
\hline Hail- Fire & $\mathrm{x} 45$ & 25 & 280 & 35 & 200 \\
\hline Hail- Others & $\mathrm{x} 46$ & 50 & 165 & 75 & 105 \\
\hline Fire - Others & $\mathrm{x} 56$ & 55 & 280 & 70 & 200 \\
\hline Diseases and Pests- Frost- Drought & $\mathrm{x} 123$ & 65 & 195 & 90 & 100 \\
\hline Diseases and Pests- Frost- Hail & $\mathrm{x} 124$ & 50 & 190 & 70 & 95 \\
\hline Diseases and Pests- Frost- Fire & $\mathrm{x} 125$ & 50 & 280 & 70 & 200 \\
\hline Diseases and Pests- Frost- Others & $\mathrm{x} 126$ & 60 & 185 & 90 & 100 \\
\hline Diseases and Pests- Drought- Hail & $\mathrm{x} 134$ & 55 & 180 & 80 & 95 \\
\hline Diseases and Pests- Drought- Fire & $\mathrm{x} 135$ & 55 & 280 & 85 & 200 \\
\hline Diseases and Pests- Drought- Others & $\mathrm{x} 136$ & 65 & 175 & 90 & 100 \\
\hline Diseases and Pests- Hail- Fire & x145 & 45 & 280 & 65 & 200 \\
\hline Diseases and Pests- Hail- Others & $\mathrm{x} 146$ & 50 & 185 & 70 & 105 \\
\hline Diseases and Pests- Fire- Others & $\mathrm{x} 156$ & 55 & 280 & 75 & 200 \\
\hline Frost- Drought- Hail & $\mathrm{x} 234$ & 55 & 190 & 85 & 105 \\
\hline Frost- Drought- Fire & $\mathrm{x} 235$ & 60 & 280 & 90 & 200 \\
\hline Frost- Drought- Others & $\mathrm{x} 236$ & 65 & 180 & 95 & 100 \\
\hline Frost- Hail- Fire & $\mathrm{x} 245$ & 40 & 280 & 60 & 200 \\
\hline Frost- Hail- Others & $\mathrm{x} 246$ & 60 & 200 & 85 & 110 \\
\hline Frost- Fire- Others & $\mathrm{x} 256$ & 55 & 280 & 75 & 200 \\
\hline Drought- Hail- Fire & x345 & 50 & 280 & 70 & 200 \\
\hline Drought- Hail- Others & x346 & 65 & 185 & 95 & 100 \\
\hline Drought- Fire- Others & x356 & 65 & 280 & 100 & 200 \\
\hline Hail- Fire- Others & $\mathrm{x} 456$ & 50 & 280 & 75 & 200 \\
\hline Diseases and Pests- Frost- Drought- Hail & $\mathrm{x} 1234$ & 80 & 200 & 110 & 120 \\
\hline Diseases and Pests- Frost- Drought- Fire & $\mathrm{x} 1235$ & 90 & 280 & 115 & 200 \\
\hline Diseases and Pests- Frost- Drought- Others & $\mathrm{x} 1236$ & 85 & 210 & 110 & 120 \\
\hline Diseases and Pests- Frost- Hail- Fire & $\mathrm{x} 1245$ & 85 & 280 & 115 & 200 \\
\hline Diseases and Pests- Frost- Hail- Others & $\mathrm{x} 1246$ & 95 & 225 & 120 & 125 \\
\hline Diseases and Pests- Frost- Fire- Others & $\mathrm{x} 1256$ & 90 & 280 & 125 & 200 \\
\hline Diseases and Pests- Drought- Hail- Fire & $\mathrm{x} 1345$ & 85 & 280 & 115 & 200 \\
\hline Diseases and Pests- Drought- Hail- Others & x1346 & 85 & 190 & 110 & 110 \\
\hline Diseases and Pests- Drought- Fire- Others & $\mathrm{x} 1356$ & 85 & 280 & 115 & 200 \\
\hline Diseases and Pests- Hail- Fire- Others & $\mathrm{x} 1456$ & 90 & 280 & 120 & 200 \\
\hline Frost- Drought- Hail- Fire & $\mathrm{x} 2345$ & 95 & 280 & 130 & 200 \\
\hline Frost- Drought- Hail- Others & $\mathrm{x} 2346$ & 100 & 225 & 135 & 120 \\
\hline Frost- Drought- Fire- Others & $\mathrm{x} 2356$ & 100 & 280 & 140 & 200 \\
\hline Frost- Hail- Fire- Others & $\mathrm{x} 2456$ & 105 & 280 & 145 & 200 \\
\hline Drought- Hail- Fire- Others & x3456 & 85 & 280 & 110 & 200 \\
\hline Diseases and Pests- Frost- Drought- Hail-Fire & $\mathrm{x} 12345$ & 100 & 280 & 140 & 200 \\
\hline Diseases and Pests- Frost- Drought- Hail- Others & x12346 & 110 & 230 & 150 & 125 \\
\hline Diseases and Pests- Frost- Drought- Fire- Others & $\mathrm{x} 12356$ & 110 & 280 & 145 & 200 \\
\hline Diseases and Pests- Frost- Hail- Fire- Others & x12456 & 110 & 280 & 155 & 200 \\
\hline Diseases and Pests- Drought- Hail-Fire- Others & $\mathrm{x} 13456$ & 100 & 280 & 135 & 200 \\
\hline Frost- Drought- Hail-Fire- Others & x23456 & 115 & 280 & 160 & 200 \\
\hline Diseases and Pests-Frost- Drought-Hail-Fire-Others & $\mathrm{x} 123456$ & 120 & 280 & 165 & 200 \\
\hline
\end{tabular}


Positivity requirement;

$\mathrm{X} \geq 0$ this is expressed in the form. In this place;

$\mathrm{C}=\left[\mathrm{c}_{1}, \mathrm{c}_{2}, \ldots, \mathrm{c}_{\mathrm{n}}\right]$,

$\mathrm{X}=\left[\begin{array}{c}\mathrm{x}_{1} \\ \mathrm{x}_{2} \\ \cdot \\ \cdot \\ \mathrm{x}_{\mathrm{n}}\end{array}\right]$

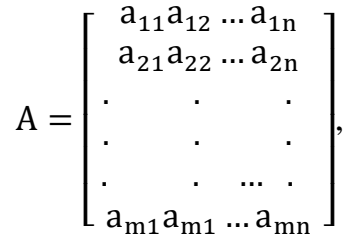

$B=\left[b_{1}, b_{2}, \ldots, b_{m}\right]^{T}=\left[\begin{array}{c}b_{1} \\ b_{2} \\ \cdot \\ \cdot \\ \cdot \\ b_{m}\end{array}\right]$,

C: $(1 \mathrm{x} \mathrm{n})$ dimensional objective function coefficients vector (Adjusted Probability of Risk),

$\mathrm{X}$ : (n x 1) dimensional decision variables vector (Risk Factors and Interactions),

A: $(\mathrm{m} \times \mathrm{n})$ dimensional constraint coefficients matrix (Frequency of Risk),

$\mathrm{B}$ : $(\mathrm{m} \times 1)$ is the vector of the values of the dimensional constraints (Effect of Risk).

The risk analysis of this study was obtained with thehelp of the version 24.1.3.CPLEX algorithm version 2.5.1.0 of the GAMS package program of the generated linear 63 different risk models.

\section{Results and Discussion}

The results of the risk models created for the wheat yield of the Konya province Hadim district are given in Table 3 in terms of farmer and insurance based minimum and maximum risk ranges in terms of yield $\left(\mathrm{kg} / \mathrm{ha}^{-1}\right)$ and wage $\left(\mathrm{TL} / \mathrm{ha}^{-1}\right)$. There are huge differences in terms of some risk factors in terms of farmers and insurance. Some of these differences are closing due to premium support. In terms of natural risks, $50 \%$ of the premium, $66.67 \%$ of the frost coverage and $60 \%$ of the drought are covered by the state (Çiftçi, 2014). However, it is thought that the district-based natural risk factors are slightly below the expectations of the farmers because they only cover the drought risk and the disease pests and other risk factors are excluded from the coverage.

Thanks to 63 different models created with linear programming logic, farmers are able to choose the natural risks they want. In this context, the farmer can provide the opportunity to pay less premiums by insuring the natural risk factors he sees as risky for his own region. Similar situations apply to health, vehicle and home insurances. For example, in a place where there is no landslide and hose risk, home and workplace owners can pay lower premiums by excluding these risks from insurance coverage.

Confidence intervals of natural risk factors in terms of farmer and insurance are given in Table 3.The amount of risk expected by the district farmer for diseases and pests is estimated to be between 5.625-52.800 $\left(\mathrm{kg} / \mathrm{ha}^{-1}\right)$.In frost risk, the amount of risk that the farmer expects is between 7,500-56,063 $\left(\mathrm{kg} / \mathrm{ha}^{-1}\right)$, while insurance is $4,688-31,688\left(\mathrm{~kg} / \mathrm{ha}^{-}\right.$ $\left.{ }^{1}\right)$. While the risk range of the farmer in drought risk is $2,400-38,438\left(\mathrm{~kg} / \mathrm{ha}^{-1}\right)$, insurance is estimated to be 1,200-23,063 (kg / $\left.\mathrm{ha}^{-1}\right)$.In addition, farmers cannot benefit from the drought risk individually, as the insurance applies a district-based drought insurance. When the hail risk is taken into account, it has been determined that the farmer is 1,035-15,600 $\left(\mathrm{kg} / \mathrm{ha}^{-1}\right)$, while there may be a loss in the range of $0.690-8,400$ $\left(\mathrm{kg} / \mathrm{ha}^{-1}\right)$ of insurance.In fire risk, farmer loss is estimated to be between 0.021-0.899 $\left(\mathrm{kg} / \mathrm{ha}^{-1}\right)$, while insurance will be in the range of $0.010-0.642\left(\mathrm{~kg}^{-} \mathrm{ha}^{-}\right.$ $\left.{ }^{1}\right)$.In case of other risks that cannot be handled individually, the farmer was found to be between 15,600-85,188 (kg / $\left.\mathrm{ha}^{-1}\right)$, while insurance was between $6,825-41,125\left(\mathrm{~kg} / \mathrm{ha}^{-1}\right)$.

Considering all natural risk factors in wheat production of Hadim district, it was 18.903-111.020 $\left(\mathrm{kg} / \mathrm{ha}^{-1}\right.$ ) and 20.831-122.344 (TL / $\mathrm{ha}^{-1}$ ) for the farmer, while in terms of insurance, the risk is expected between 30.854-76.241 (kg/ ha $\left.{ }^{-1}\right)$ and 34.001-84.018 (TL / ha ${ }^{-1}$ ). (Table 3). When an evaluation is made in terms of long years, the risk expected by the district farmers in wheat production is $64.962\left(\mathrm{~kg} / \mathrm{ha}^{-1}\right)-71.588\left(\mathrm{TL} / \mathrm{ha}^{-1}\right)$, while the risk amount expected by insurance companies is 53.548 $\left(\mathrm{kg} / \mathrm{ha}^{-1}\right) \quad-59.009 \quad\left(\mathrm{TL} / \mathrm{ha}^{-1}\right) \quad($ Table 4)

Table 3

Results of Farmer and Insurance Risk Analysis in Wheat Production of Hadim District, Konya

\begin{tabular}{|c|c|c|c|c|c|c|c|c|c|}
\hline \multirow{2}{*}{ Natural Risks (Models) } & \multirow{2}{*}{ Symbols } & \multicolumn{2}{|c|}{$\begin{array}{c}\text { Farmer Risk } \\
\left(\mathrm{kg} / \mathrm{ha}^{-1}\right)\end{array}$} & \multicolumn{2}{|c|}{$\begin{array}{c}\text { Insurance Risk } \\
\left(\mathrm{kg} / \mathrm{ha}^{-1}\right)\end{array}$} & \multicolumn{2}{|c|}{$\begin{array}{c}\text { Farmer Risk } \\
\left(* \mathrm{TL} / \mathrm{ha}^{-1}\right)\end{array}$} & \multicolumn{2}{|c|}{$\begin{array}{c}\text { Insurance Risk } \\
\left(* \mathrm{TL} / \mathrm{ha}^{-1}\right)\end{array}$} \\
\hline & & Min & Max & Min & Max & Min & $\operatorname{Max}$ & Min & $\operatorname{Max}$ \\
\hline Diseases and Pests & $\mathrm{x} 1$ & 5.625 & 52.800 & 0.000 & 0.000 & 6.199 & 58.186 & 0.000 & 0.000 \\
\hline Frost & $\mathrm{x} 2$ & 7.500 & 56.063 & 4.688 & 31.688 & 8.265 & 61.781 & 5.166 & 34.920 \\
\hline Drought & $\mathrm{x} 3$ & 2.400 & 38.438 & 1.200 & 23.063 & 2.645 & 42.359 & 1.322 & 25.415 \\
\hline Hail & $\mathrm{x} 4$ & 1.035 & 15.600 & 0.690 & 8.400 & 1.141 & 17.191 & 0.760 & 9.257 \\
\hline Fire & $\times 5$ & 0.021 & 0.899 & 0.010 & 0.642 & 0.023 & 0.991 & 0.011 & 0.707 \\
\hline
\end{tabular}


Altay and Keskin / Selcuk J Agr Food Sci, (2021) 35 (1), 1-11

Table 3

Results of Farmer and Insurance Risk Analysis in Wheat Production of Hadim District, Konya

\begin{tabular}{|c|c|c|c|c|c|c|c|c|c|}
\hline Others & $\mathrm{x} 6$ & 15.600 & 85.188 & 6.825 & 41.125 & 17.191 & 93.877 & 7.521 & 45.320 \\
\hline Diseases and Pests- Frost & $\mathrm{x} 12$ & 8.700 & 44.500 & 8.900 & 21.250 & 9.587 & 49.039 & 9.808 & 23.418 \\
\hline Diseases and Pests- Drought & $\mathrm{x} 13$ & 5.675 & 37.500 & 3.025 & 15.500 & 6.254 & 41.325 & 3.334 & 17.081 \\
\hline Diseases and Pests- Hail & $\mathrm{x} 14$ & 5.220 & 31.680 & 1.980 & 7.360 & 5.752 & 34.911 & 2.182 & 8.111 \\
\hline Diseases and Pests- Fire & $\mathrm{x} 15$ & 4.513 & 24.661 & 0.060 & 0.737 & 4.973 & 27.176 & 0.066 & 0.812 \\
\hline Diseases and Pests- Others & $\mathrm{x} 16$ & 10.650 & 54.750 & 14.925 & 31.000 & 11.736 & 60.335 & 16.447 & 34.162 \\
\hline Frost- Drought & $\mathrm{x} 23$ & 5.012 & 40.625 & 8.488 & 26.562 & 5.523 & 44.769 & 9.354 & 29.271 \\
\hline Frost- Hail & $\mathrm{x} 24$ & 4.508 & 34.050 & 7.148 & 20.050 & 4.968 & 37.523 & 7.877 & 22.095 \\
\hline Frost- Fire & $\mathrm{x} 25$ & 3.765 & 29.469 & 6.027 & 16.816 & 4.149 & 32.475 & 6.642 & 18.531 \\
\hline Frost- Others & $\mathrm{x} 26$ & 10.238 & 48.438 & 19.913 & 29.687 & 11.282 & 53.379 & 21.944 & 32.715 \\
\hline Drought- Hail & $\mathrm{x} 34$ & 1.653 & 26.750 & 2.983 & 16.150 & 1.822 & 29.479 & 3.287 & 17.797 \\
\hline Drought- Fire & $\mathrm{x} 35$ & 1.012 & 19.592 & 2.022 & 11.878 & 1.115 & 21.590 & 2.228 & 13.090 \\
\hline Drought- Others & $\mathrm{x} 36$ & 7.237 & 48.438 & 14.713 & 29.687 & 7.975 & 53.379 & 16.214 & 32.715 \\
\hline Hail- Fire & $\mathrm{x} 45$ & 0.611 & 10.930 & 0.921 & 6.049 & 0.673 & 12.045 & 1.015 & 6.666 \\
\hline Hail- Others & $\mathrm{x} 46$ & 6.075 & 41.150 & 13.238 & 27.500 & 6.695 & 45.347 & 14.588 & 30.305 \\
\hline Fire - Others & $\mathrm{x} 56$ & 5.278 & 36.865 & 12.031 & 25.450 & 5.816 & 40.625 & 13.258 & 28.046 \\
\hline Diseases and Pests- Frost- Drought & $\mathrm{x} 123$ & 10.186 & 70.445 & 11.730 & 37.062 & 11.225 & 77.630 & 12.926 & 40.842 \\
\hline Diseases and Pests- Frost- Hail & x124 & 9.609 & 53.509 & 10.572 & 27.190 & 10.589 & 58.967 & 11.650 & 29.963 \\
\hline Diseases and Pests- Frost- Fire & $\mathrm{x} 125$ & 8.719 & 45.223 & 8.948 & 21.955 & 9.608 & 49.836 & 9.861 & 24.194 \\
\hline Diseases and Pests- Frost & $\mathrm{x} 126$ & 16.222 & 73.946 & 24.440 & 41.937 & 17.877 & 81.488 & 26.933 & 46.215 \\
\hline Diseases and Pests- Drought- Hail & $\mathrm{x} 134$ & 6.464 & 47.392 & 5.112 & 22.540 & 7.123 & 52.226 & 5.633 & 24.839 \\
\hline Diseases and Pests- Drought- Fire & x135 & 5.690 & 38.247 & 3.088 & 16.265 & 6.270 & 42.148 & 3.403 & 17.924 \\
\hline Diseases and Pests- Drought- Others & x136 & 12.861 & 70.839 & 17.980 & 42.438 & 14.173 & 78.065 & 19.814 & 46.767 \\
\hline Diseases and Pests- Hail- Fire & $\mathrm{x} 145$ & 5.243 & 32.013 & 2.055 & 7.928 & 5.778 & 35.278 & 2.265 & 8.737 \\
\hline Diseases and Pests- Hail- Others & $\mathrm{x} 146$ & 11.626 & 60.598 & 16.837 & 35.680 & 12.812 & 66.779 & 18.554 & 39.319 \\
\hline d Pests- Fire- Others & x156 & 10.683 & 55.359 & 14.982 & 31.600 & 11.773 & 61.006 & 16.510 & 34.823 \\
\hline Frost- Drought- Hail & $\mathrm{x} 234$ & 5.835 & 52.075 & 9.737 & 32.188 & 6.430 & 57.387 & 10.730 & 35.471 \\
\hline Frost- & $\mathrm{x} 235$ & 5.034 & 41.548 & 8.517 & 27.245 & 5.547 & 45.786 & 9.386 & 30.024 \\
\hline Frost- Drought- Others & $\mathrm{x} 236$ & 11.323 & 75.312 & 21.307 & 43.750 & 12.478 & 82.994 & 23.480 & 48.213 \\
\hline Frost- Hail- Fire & $\mathrm{x} 245$ & 4.523 & 34.749 & 7.176 & 20.590 & 4.984 & 38.293 & 7.908 & 22.690 \\
\hline Frost- Hail- Others & $\mathrm{x} 246$ & 11.261 & 59.238 & 21.455 & 35.338 & 12.410 & 65.280 & 23.643 & 38.942 \\
\hline Frost- Fire- Others & $\mathrm{x} 256$ & 10.266 & 49.285 & 19.951 & 30.340 & 11.313 & 54.312 & 21.986 & 33.435 \\
\hline Drought- Hail- Fire & $\mathrm{x} 345$ & 1.665 & 27.464 & 3.006 & 16.705 & 1.835 & 30.265 & 3.313 & 18.409 \\
\hline Drou & x346 & 8.130 & 57.862 & 16.054 & 34.387 & 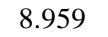 & 63.764 & 17.692 & 37.894 \\
\hline Drought- Fire- Others & $\mathrm{x} 356$ & 7.268 & 49.285 & 14.746 & 30.340 & 8.009 & 54.312 & 16.250 & 33.435 \\
\hline Hail- Fire- Others & $\mathrm{x} 456$ & 6.104 & 41.789 & 13.269 & 27.995 & 6.727 & 46.051 & 14.622 & 30.850 \\
\hline Diseases and Pests- Frost- Drought- Hail & x1234 & 10.824 & 82.422 & 12.557 & 45.327 & 11.928 & 90.829 & 13.838 & 49.950 \\
\hline Diseases and Pests- Frost- Drought- Fire & x1235 & 9.538 & 71.552 & 10.974 & 37.932 & 10.511 & 78.850 & 12.093 & 41.801 \\
\hline Diseases and Pests- Frost- Drought- Others & x1236 & 17.018 & 112.905 & 25.290 & 63.062 & 18.754 & 124.421 & 27.870 & 69.494 \\
\hline Diseases and Pests- Frost- Hail- Fire & $\mathrm{x} 1245$ & 9.204 & 54.381 & 10.304 & 27.892 & 10.143 & 59.928 & 11.355 & 30.737 \\
\hline Diseases and Pests- Frost- Hail- Others & x1246 & 16.072 & 95.982 & 24.274 & 50.149 & 17.711 & 105.772 & 26.750 & 55.264 \\
\hline Dise & 56 & 1 & 20 & 13 & 78 & 16 & 72 & 24.699 & 47.141 \\
\hline Diseases and Pests- Droug & $\mathrm{x} 1345$ & 5.791 & 48.321 & 4.254 & 23.257 & 6.382 & 53.250 & 4.688 & 25.629 \\
\hline Diseases and Pests- Drou & $\mathrm{x} 1346$ & 12.173 & 95.804 & 15.633 & 48.895 & 13.415 & 105.576 & 17.228 & 53.882 \\
\hline Diseases and Pests- Drought- Fire- Others & $\mathrm{x} 1356$ & 11.260 & 71.926 & 14.527 & 41.966 & 12.409 & 79.262 & 16.009 & 46.247 \\
\hline Diseases and Pests- Hail- Fire- Others & x1456 & 10.438 & 59.760 & 12.811 & 36.337 & 11.503 & 65.856 & 14.118 & 40.043 \\
\hline Frost- Drought- Hail- Fire & x2345 & 5.520 & 52.923 & 9.100 & 32.885 & 6.083 & 58.321 & 10.028 & 36.239 \\
\hline Frost- Drought- Hail- Others & $\mathrm{x} 2346$ & 12.263 & 96.668 & 21.390 & 52.675 & 13.514 & 106.528 & 23.572 & 58.048 \\
\hline Frost- Drought- Fire- Others & x2356 & 11.498 & 77.866 & 20.230 & 45.659 & 12.671 & 85.808 & 22.293 & 50.316 \\
\hline Frost- Hail- Fire- Others & $\mathrm{x} 2456$ & 10.427 & 66.990 & 18.739 & 38.570 & 11.491 & 73.823 & 20.650 & 42.504 \\
\hline Drought- Hail- Fire- Others & x3456 & 6.906 & 58.725 & 13.722 & 35.100 & 7.610 & 64.715 & 15.122 & 38.680 \\
\hline Diseases and Pests- Frost- Droug & $\mathrm{x} 12345$ & 11.032 & 83.274 & 13.936 & 46.228 & 12.157 & 91.768 & 15.357 & 50.943 \\
\hline $\begin{array}{l}\text { Diseases and Pests- Frost- Drought- Hail- } \\
\text { Others }\end{array}$ & x12346 & 1 & 132.332 & 08 & 75.320 & 20.134 & 30 & .510 & 83.003 \\
\hline $\begin{array}{l}\text { Diseases and Pests- Frost- Drought- Fire- } \\
\text { Others }\end{array}$ & x12356 & 17.701 & 114.144 & 28.625 & 177 & 07 & 125.787 & 31.545 & 70.723 \\
\hline Diseases and Pests- Frost- Hail- Fire- Others & $\mathrm{x} 12456$ & 13.545 & 89.930 & 26.599 & 51.103 & 14.927 & 99.103 & 29.312 & 56.316 \\
\hline $\begin{array}{l}\text { Diseases and Pests- Drought- Hail-Fire- } \\
\text { Others }\end{array}$ & $\mathrm{x} 13456$ & 14.688 & 84.761 & 20.436 & 49.473 & 16.186 & 93.407 & 22.520 & 54.519 \\
\hline Frost- Drought- Hail-Fire- Others & $\mathrm{x} 23456$ & 12.815 & 92.166 & 25.312 & 53.581 & 14.122 & 101.567 & 27.894 & 59.046 \\
\hline $\begin{array}{l}\text { Diseases and Pests-Frost- Drought-Hail-Fire- } \\
\text { Others }\end{array}$ & x123456 & 18.903 & 111.020 & 30.854 & 76.241 & 20.831 & 122.344 & 34.001 & 84.018 \\
\hline
\end{tabular}

*The unit price of wheat kilogram is taken as $1.102 \mathrm{TL}$ 
Altay and Keskin / Selcuk J Agr Food Sci, (2021) 35 (1), 1-11

Table 4

Expected Results of Farmer and Insurance Risk Analysis in Wheat Production of Hadim District, Konya

\begin{tabular}{|c|c|c|c|c|c|}
\hline \multirow{2}{*}{ Natural Risks (Models) } & \multirow{2}{*}{ Symbols } & $\begin{array}{c}\text { Farmer Risk } \\
\left(\mathrm{kg} / \mathrm{ha}^{-1}\right)\end{array}$ & $\begin{array}{c}\text { Insurance Risk } \\
\left(\mathrm{kg} / \mathrm{ha}^{-1}\right)\end{array}$ & $\begin{array}{l}\text { Farmer Risk } \\
\left(\mathrm{kg} / \mathrm{ha}^{-1}\right)\end{array}$ & $\begin{array}{c}\text { Insurance Risk } \\
\left(\mathrm{kg} / \mathrm{ha}^{-1}\right)\end{array}$ \\
\hline & & $\begin{array}{l}\text { Minimum } \\
\text { Expected }\end{array}$ & Minimum Expected & $\begin{array}{l}\text { Maximum } \\
\text { Expected }\end{array}$ & $\begin{array}{l}\text { Maximum } \\
\text { Expected }\end{array}$ \\
\hline Diseases and Pests & $\mathrm{x} 1$ & 29.213 & 0.000 & 32.192 & 0.000 \\
\hline Frost & $\mathrm{x} 2$ & 31.782 & 18.188 & 35.023 & 20.043 \\
\hline Drought & $\mathrm{x} 3$ & 20.419 & 12.132 & 22.502 & 13.369 \\
\hline Hail & $\mathrm{x} 4$ & 8.318 & 4.545 & 9.166 & 5.009 \\
\hline Fire & $x 5$ & 0.460 & 0.326 & 0.507 & 0.359 \\
\hline Others & $\mathrm{x} 6$ & 50.394 & 23.975 & 55.534 & 26.420 \\
\hline Diseases and Pests- Frost & $\mathrm{x} 12$ & 26.600 & 15.075 & 29.313 & 16.613 \\
\hline Diseases and Pests- Drought & $\mathrm{x} 13$ & 21.588 & 9.263 & 23.789 & 10.207 \\
\hline Diseases and Pests- Hail & $\mathrm{x} 14$ & 18.450 & 4.670 & 20.332 & 5.146 \\
\hline Diseases and Pests- Fire & $\mathrm{x} 15$ & 14.587 & 0.399 & 16.075 & 0.439 \\
\hline Diseases and Pests- Others & $\mathrm{x} 16$ & 32.700 & 22.963 & 36.035 & 25.305 \\
\hline Frost- Drought & $\mathrm{x} 23$ & 22.819 & 17.525 & 25.146 & 19.313 \\
\hline Frost- Hail & $\mathrm{x} 24$ & 19.279 & 13.599 & 21.245 & 14.986 \\
\hline Frost- Fire & $\mathrm{x} 25$ & 16.617 & 11.422 & 18.312 & 12.586 \\
\hline Frost- Others & $\mathrm{x} 26$ & 29.338 & 24.800 & 32.330 & 27.330 \\
\hline Drought- Hail & $\mathrm{x} 34$ & 14.202 & 9.567 & 15.650 & 10.542 \\
\hline Drought- Fire & $\mathrm{x} 35$ & 10.302 & 6.950 & 11.353 & 7.659 \\
\hline Drought- Others & x36 & 27.838 & 22.200 & 30.677 & 24.464 \\
\hline Hail- Fire & $\mathrm{x} 45$ & 5.771 & 3.485 & 6.359 & 3.840 \\
\hline Hail- Others & $\mathrm{x} 46$ & 23.613 & 20.369 & 26.021 & 22.447 \\
\hline Fire - Others & x56 & 21.072 & 18.741 & 23.221 & 20.652 \\
\hline Diseases and Pests- Frost- Drought & $\mathrm{x} 123$ & 40.316 & 24.396 & 44.428 & 26.884 \\
\hline Diseases and Pests- Frost- Hail & $\mathrm{x} 124$ & 31.559 & 18.881 & 34.778 & 20.807 \\
\hline Diseases and Pests- Frost- Fire & $\mathrm{x} 125$ & 26.971 & 15.452 & 29.722 & 17.028 \\
\hline Diseases and Pests- Frost- Others & $\mathrm{x} 126$ & 45.084 & 33.189 & 49.683 & 36.574 \\
\hline Diseases and Pests- Drought- Hail & $\mathrm{x} 134$ & 26.928 & 13.826 & 29.675 & 15.236 \\
\hline Diseases and Pests- Drought- Fire & $\mathrm{x} 135$ & 21.969 & 9.677 & 24.209 & 10.664 \\
\hline Diseases and Pests- Drought- Others & x136 & 41.850 & 30.209 & 46.119 & 33.290 \\
\hline Diseases and Pests- Hail- Fire & $\mathrm{x} 145$ & 18.628 & 4.992 & 20.528 & 5.501 \\
\hline Diseases and Pests- Hail- Others & x146 & 36.112 & 26.259 & 39.795 & 28.937 \\
\hline Diseases and Pests- Fire- Others & $\mathrm{x} 156$ & 33.021 & 23.291 & 36.389 & 25.667 \\
\hline Frost- Drought- Hail & $\mathrm{x} 234$ & 28.955 & 20.963 & 31.908 & 23.101 \\
\hline Frost- Drought- Fire & $\mathrm{x} 235$ & 23.291 & 17.881 & 25.667 & 19.705 \\
\hline Frost- Drought- Others & $\mathrm{x} 236$ & 43.318 & 32.529 & 47.736 & 35.846 \\
\hline Frost- Hail- Fire & $\mathrm{x} 245$ & 19.636 & 13.883 & 21.639 & 15.299 \\
\hline Frost- Hail- Others & $\mathrm{x} 246$ & 35.250 & 28.397 & 38.845 & 31.293 \\
\hline Frost- Fire- Others & $\mathrm{x} 256$ & 29.776 & 25.146 & 32.813 & 27.710 \\
\hline Drought- Hail- Fire & x345 & 14.565 & 9.856 & 16.050 & 10.861 \\
\hline Drought- Hail- Others & x346 & 32.996 & 25.221 & 36.362 & 27.793 \\
\hline Drought- Fire- Others & x356 & 28.277 & 22.543 & 31.161 & 24.842 \\
\hline Hail- Fire- Others & $\mathrm{x} 456$ & 23.947 & 20.632 & 26.389 & 22.736 \\
\hline Diseases and Pests- Frost- Drought- Hail & x1234 & 46.623 & 28.942 & 51.379 & 31.894 \\
\hline Diseases and Pests- Frost- Drought- Fire & x1235 & 40.545 & 24.453 & 44.681 & 26.947 \\
\hline Diseases and Pests- Frost- Drought- Others & x1236 & 64.962 & 44.176 & 71.588 & 48.682 \\
\hline Diseases and Pests- Frost- Hail- Fire & x1245 & 31.793 & 19.098 & 35.036 & 21.046 \\
\hline Diseases and Pests- Frost- Hail- Others & x1246 & 56.027 & 37.212 & 61.742 & 41.007 \\
\hline Diseases and Pests- Frost- Fire- Others & $\mathrm{x} 1256$ & 45.018 & 32.596 & 49.610 & 35.920 \\
\hline Diseases and Pests- Drought- Hail- Fire & $\mathrm{x} 1345$ & 27.056 & 13.756 & 29.816 & 15.159 \\
\hline Diseases and Pests- Drought- Hail- Others & x1346 & 53.989 & 32.264 & 59.496 & 35.555 \\
\hline Diseases and Pests- Drought- Fire- Others & x1356 & 41.593 & 28.247 & 45.836 & 31.128 \\
\hline Diseases and Pests- Hail- Fire- Others & x1456 & 35.099 & 24.574 & 38.680 & 27.081 \\
\hline Frost- Drought- Hail- Fire & $\mathrm{x} 2345$ & 29.222 & 20.993 & 32.202 & 23.134 \\
\hline Frost- Drought- Hail- Others & $\mathrm{x} 2346$ & 54.466 & 37.033 & 60.021 & 40.810 \\
\hline Frost- Drought- Fire- Others & $\mathrm{x} 2356$ & 44.682 & 32.945 & 49.240 & 36.305 \\
\hline Frost- Hail- Fire- Others & $x 2456$ & 38.709 & 28.655 & 42.657 & 31.577 \\
\hline Drought- Hail- Fire- Others & $\mathrm{x} 3456$ & 32.816 & 24.411 & 36.163 & 26.901 \\
\hline Diseases and Pests- Frost- Drought- Hail-Fire & $\mathrm{x} 12345$ & 47.153 & 30.082 & 51.963 & 33.150 \\
\hline Diseases and Pests- Frost- Drought- Hail- Others & x12346 & 75.301 & 52.864 & 82.982 & 58.256 \\
\hline Diseases and Pests- Frost- Drought- Fire- Others & x12356 & 65.923 & 46.401 & 72.647 & 51.134 \\
\hline Diseases and Pests- Frost- Hail- Fire- Others & x12456 & 51.738 & 38.851 & 57.015 & 42.814 \\
\hline Diseases and Pests- Drought- Hail-Fire- Others & x13456 & 49.725 & 34.955 & 54.796 & 38.520 \\
\hline Frost- Drought- Hail-Fire- Others & $\mathrm{x} 23456$ & 52.491 & 39.447 & 57.845 & 43.470 \\
\hline Diseases and Pests-Frost- Drought-Hail-Fire-Others & $\mathrm{x} 123456$ & 64.962 & 53.548 & 71.588 & 59.009 \\
\hline
\end{tabular}


Altay and Keskin / Selcuk J Agr Food Sci, (2021) 35 (1), 1-11

Table 5

Premiums and Compensation Results in terms of Farmers and Insurance in Wheat Production of Hadim District, Konya

\begin{tabular}{|c|c|c|c|c|c|c|c|c|c|}
\hline \multirow[t]{2}{*}{ Natural Risks (Models) } & \multirow[t]{2}{*}{ Symbols } & \multicolumn{2}{|c|}{$\begin{array}{c}\text { Farmer Risk } \\
\left(\mathrm{kg} / \mathrm{ha}^{-1}\right)\end{array}$} & \multicolumn{2}{|c|}{$\begin{array}{c}\text { Insurance Risk } \\
\left(\mathrm{kg} / \mathrm{ha}^{-1}\right)\end{array}$} & \multicolumn{2}{|c|}{$\begin{array}{c}\text { Farmer Risk } \\
\left(* \mathrm{TL} / \mathrm{ha}^{-1}\right)\end{array}$} & \multicolumn{2}{|c|}{$\begin{array}{c}\text { Insurance Risk } \\
\left(* \mathrm{TL} / \mathrm{ha}^{-1}\right)\end{array}$} \\
\hline & & Prem & Comp & Prem & Comp & Prem & Comp & Prem & Comp \\
\hline Diseases and Pests & $\mathrm{x} 1$ & 5.625 & 52.800 & 0.000 & 0.000 & 6.199 & 58.186 & 0.000 & 0.000 \\
\hline Frost & $\mathrm{x} 2$ & 7.500 & 56.063 & 4.688 & 31.688 & 8.265 & 61.781 & 5.166 & 34.920 \\
\hline Drought & $\mathrm{x} 3$ & 2.400 & 38.438 & 1.200 & 23.063 & 2.645 & 42.359 & 1.322 & 25.415 \\
\hline Hail & $\mathrm{x} 4$ & 1.035 & 15.600 & 0.690 & 8.400 & 1.141 & 17.191 & 0.760 & 9.257 \\
\hline Fire & $\mathrm{x} 5$ & 0.021 & 0.899 & 0.010 & 0.642 & 0.023 & 0.991 & 0.011 & 0.707 \\
\hline Others & x6 & 15.600 & 85.188 & 6.825 & 41.125 & 17.191 & 93.877 & 7.521 & 45.320 \\
\hline Diseases and Pests- Frost & $\mathrm{x} 12$ & 8.700 & 44.500 & 8.900 & 21.250 & 9.587 & 49.039 & 9.808 & 23.418 \\
\hline Diseases and Pests- Drought & $\mathrm{x} 13$ & 5.675 & 37.500 & 3.025 & 15.500 & 6.254 & 41.325 & 3.334 & 17.081 \\
\hline Diseases and Pests- Hail & $\mathrm{x} 14$ & 5.220 & 31.680 & 1.980 & 7.360 & 5.752 & 34.911 & 2.182 & 8.111 \\
\hline Diseases and Pests- Fire & $\mathrm{x} 15$ & 4.513 & 24.661 & 0.060 & 0.737 & 4.973 & 27.176 & 0.066 & 0.812 \\
\hline Diseases and Pests- Others & $\mathrm{x} 16$ & 10.650 & 54.750 & 14.925 & 31.000 & 11.736 & 60.335 & 16.447 & 34.162 \\
\hline Frost- Drought & $\mathrm{x} 23$ & 5.012 & 40.625 & 8.488 & 26.562 & 5.523 & 44.769 & 9.354 & 29.271 \\
\hline Frost- Hail & $\mathrm{x} 24$ & 4.508 & 34.050 & 7.148 & 20.050 & 4.968 & 37.523 & 7.877 & 22.095 \\
\hline Frost- Fire & $\mathrm{x} 25$ & 3.765 & 29.469 & 6.027 & 16.816 & 4.149 & 32.475 & 6.642 & 18.531 \\
\hline Frost- Others & $\mathrm{x} 26$ & 10.238 & 48.438 & 19.913 & 29.687 & 11.282 & 53.379 & 21.944 & 32.715 \\
\hline Drought- Hail & x34 & 1.653 & 26.750 & 2.983 & 16.150 & 1.822 & 29.479 & 3.287 & 17.797 \\
\hline Drought- Fire & $\mathrm{x} 35$ & 1.012 & 19.592 & 2.022 & 11.878 & 1.115 & 21.590 & 2.228 & 13.090 \\
\hline Drought- Others & x36 & 7.237 & 48.438 & 14.713 & 29.687 & 7.975 & 53.379 & 16.214 & 32.715 \\
\hline Hail- Fire & $\mathrm{x} 45$ & 0.611 & 10.930 & 0.921 & 6.049 & 0.673 & 12.045 & 1.015 & 6.666 \\
\hline Hail- Others & $\mathrm{x} 46$ & 6.075 & 41.150 & 13.238 & 27.500 & 6.695 & 45.347 & 14.588 & 30.305 \\
\hline Fire - Others & $\mathrm{x} 56$ & 5.278 & 36.865 & 12.031 & 25.450 & 5.816 & 40.625 & 13.258 & 28.046 \\
\hline Diseases and Pests- Frost- Drought & $\mathrm{x} 123$ & 10.186 & 70.445 & 11.730 & 37.062 & 11.225 & 77.630 & 12.926 & 40.842 \\
\hline Diseases and Pests- Frost- Hail & $\mathrm{x} 124$ & 9.609 & 53.509 & 10.572 & 27.190 & 10.589 & 58.967 & 11.650 & 29.963 \\
\hline Diseases and Pests- Frost- Fire & $\mathrm{x} 125$ & 8.719 & 45.223 & 8.948 & 21.955 & 9.608 & 49.836 & 9.861 & 24.194 \\
\hline Diseases and Pests- Frost- Others & $\mathrm{x} 126$ & 16.222 & 73.946 & 24.440 & 41.937 & 17.877 & 81.488 & 26.933 & 46.215 \\
\hline Diseases and Pests- Drought- Hail & $\mathrm{x} 134$ & 6.464 & 47.392 & 5.112 & 22.540 & 7.123 & 52.226 & 5.633 & 24.839 \\
\hline Diseases and Pests- Drought- Fire & $\mathrm{x} 135$ & 5.690 & 38.247 & 3.088 & 16.265 & 6.270 & 42.148 & 3.403 & 17.924 \\
\hline Diseases and Pests- Drought- Others & $\mathrm{x} 136$ & 12.861 & 70.839 & 17.980 & 42.438 & 14.173 & 78.065 & 19.814 & 46.767 \\
\hline Diseases and Pests- Hail- Fire & $\mathrm{x} 145$ & 5.243 & 32.013 & 2.055 & 7.928 & 5.778 & 35.278 & 2.265 & 8.737 \\
\hline Diseases and Pests- Hail- Others & x146 & 11.626 & 60.598 & 16.837 & 35.680 & 12.812 & 66.779 & 18.554 & 39.319 \\
\hline Diseases and Pests- Fire- Others & $\mathrm{x} 156$ & 10.683 & 55.359 & 14.982 & 31.600 & 11.773 & 61.006 & 16.510 & 34.823 \\
\hline Frost- Drought- Hail & $\mathrm{x} 234$ & 5.835 & 52.075 & 9.737 & 32.188 & 6.430 & 57.387 & 10.730 & 35.471 \\
\hline Frost- Drought- Fire & $\mathrm{x} 235$ & 5.034 & 41.548 & 8.517 & 27.245 & 5.547 & 45.786 & 9.386 & 30.024 \\
\hline Frost- Drought- Others & $\mathrm{x} 236$ & 11.323 & 75.312 & 21.307 & 43.750 & 12.478 & 82.994 & 23.480 & 48.213 \\
\hline Frost- Hail- Fire & $\mathrm{x} 245$ & 4.523 & 34.749 & 7.176 & 20.590 & 4.984 & 38.293 & 7.908 & 22.690 \\
\hline Frost- Hail- Others & $\mathrm{x} 246$ & 11.261 & 59.238 & 21.455 & 35.338 & 12.410 & 65.280 & 23.643 & 38.942 \\
\hline Frost- Fire- Others & $\mathrm{x} 256$ & 10.266 & 49.285 & 19.951 & 30.340 & 11.313 & 54.312 & 21.986 & 33.435 \\
\hline Drought- Hail- Fire & x345 & 1.665 & 27.464 & 3.006 & 16.705 & 1.835 & 30.265 & 3.313 & 18.409 \\
\hline Drought- Hail- Others & x346 & 8.130 & 57.862 & 16.054 & 34.387 & 8.959 & 63.764 & 17.692 & 37.894 \\
\hline Drought- Fire- Others & x356 & 7.268 & 49.285 & 14.746 & 30.340 & 8.009 & 54.312 & 16.250 & 33.435 \\
\hline Hail- Fire- Others & $\mathrm{x} 456$ & 6.104 & 41.789 & 13.269 & 27.995 & 6.727 & 46.051 & 14.622 & 30.850 \\
\hline Diseases and Pests- Frost- & x1234 & 10.824 & 82.422 & 12.557 & 45.327 & 11.928 & 90.829 & 13.838 & 49.950 \\
\hline Diseases and Pests- Frost- Drought- Fire & $\mathrm{x} 1235$ & 9.538 & 71.552 & 10.974 & 37.932 & 10.511 & 78.850 & 12.093 & 41.801 \\
\hline Diseases and Pests- Frost- Drought- Others & $\mathrm{x} 1236$ & 17.018 & 112.905 & 25.290 & 63.062 & 18.754 & 124.421 & 27.870 & 69.494 \\
\hline Diseases and Pests- Frost- Hail- Fire & $\mathrm{x} 1245$ & 9.204 & 54.381 & 10.304 & 27.892 & 10.143 & 59.928 & 11.355 & 30.737 \\
\hline Diseases and Pests- Frost- Hail- Others & $\mathrm{x} 1246$ & 16.072 & 95.982 & 24.274 & 50.149 & 17.711 & 105.772 & 26.750 & 55.264 \\
\hline Diseases and Pests- Frost- Fire- Others & $\mathrm{x} 1256$ & 15.015 & 75.020 & 22.413 & 42.778 & 16.547 & 82.672 & 24.699 & 47.141 \\
\hline Diseases and Pests- Drought- Hail- Fire & $\mathrm{x} 1345$ & 5.791 & 48.321 & 4.254 & 23.257 & 6.382 & 53.250 & 4.688 & 25.629 \\
\hline Diseases and Pests- Drought- Hail- Others & x1346 & 12.173 & 95.804 & 15.633 & 48.895 & 13.415 & 105.576 & 17.228 & 53.882 \\
\hline Diseases and Pests- Drought- Fire- Others & $\mathrm{x} 1356$ & 11.260 & 71.926 & 14.527 & 41.966 & 12.409 & 79.262 & 16.009 & 46.247 \\
\hline Diseases and Pests- Hail- Fire- Others & x1456 & 10.438 & 59.760 & 12.811 & 36.337 & 11.503 & 65.856 & 14.118 & 40.043 \\
\hline Frost- Drought- Hail- Fire & x2345 & 5.520 & 52.923 & 9.100 & 32.885 & 6.083 & 58.321 & 10.028 & 36.239 \\
\hline Frost- Drought- Hail- Others & x2346 & 12.263 & 96.668 & 21.390 & 52.675 & 13.514 & 106.528 & 23.572 & 58.048 \\
\hline Frost- Drought- Fire- Others & $\mathrm{x} 2356$ & 11.498 & 77.866 & 20.230 & 45.659 & 12.671 & 85.808 & 22.293 & 50.316 \\
\hline Frost- Hail- Fire- Others & $\mathrm{x} 2456$ & 10.427 & 66.990 & 18.739 & 38.570 & 11.491 & 73.823 & 20.650 & 42.504 \\
\hline Drought- Hail- Fire- Others & x3456 & 6.906 & 58.725 & 13.722 & 35.100 & 7.610 & 64.715 & 15.122 & 38.680 \\
\hline Diseases and Pests- Frost- Drought- Hail-Fire & $\mathrm{x} 12345$ & 11.032 & 83.274 & 13.936 & 46.228 & 12.157 & 91.768 & 15.357 & 50.943 \\
\hline Diseases and Pests- Frost- Drought- Hail- Others & $\mathrm{x} 12346$ & 18.270 & 132.332 & 30.408 & 75.320 & 20.134 & 145.830 & 33.510 & 83.003 \\
\hline Diseases and Pests- Frost- Drought- Fire- Others & $\mathrm{x} 12356$ & 17.701 & 114.144 & 28.625 & 64.177 & 19.507 & 125.787 & 31.545 & 70.723 \\
\hline Diseases and Pests- Frost- Hail- Fire- Others & x12456 & 13.545 & 89.930 & 26.599 & 51.103 & 14.927 & 99.103 & 29.312 & 56.316 \\
\hline Diseases and Pests- Drought- Hail-Fire- Others & $\mathrm{x} 13456$ & 14.688 & 84.761 & 20.436 & 49.473 & 16.186 & 93.407 & 22.520 & 54.519 \\
\hline Frost- Drought- Hail-Fire- Others & $\mathrm{x} 23456$ & 12.815 & 92.166 & 25.312 & 53.581 & 14.122 & 101.567 & 27.894 & 59.046 \\
\hline Diseases and Pests-Frost- Drought-Hail-Fire-Others & x123456 & 18.903 & 111.020 & 30.854 & 76.241 & 20.831 & 122.344 & 34.001 & 84.018 \\
\hline
\end{tabular}
(Pre: Premium, Comp: Compensation)

Considering the natural risks individually for Hadim district, the farmer pays 6.199 (TL / ha-1) premiums and expects a compensation of 58.186 (TL/ ha-1), although diseases and pests are not covered by insurance. In the event of frost risk, the farmer pays 8.265 (TL / ha-1) premium and waits for 61.781 (TL / 
ha-1) compensation, while insurance companies pay $20.043\left(\mathrm{TL} / \mathrm{ha}^{-1}\right.$ ) premium 34.920 (TL / ha-1) It has been estimated. The formation of the drought situation, farmers 2,645 (TL / ha ${ }^{-1}$ ), premium pay, 42.359 (TL / $\mathrm{ha}^{-1}$ ) while waiting for compensation, the insurance companies 13.369 ( $£ /$ ha-1) premium 25.415 (TL / ha ${ }^{-}$ $\left.{ }^{1}\right)$ estimated that paying compensation. For hail risk, the premium prices of the farmer and insurance were estimated to be 1.141 (TL / ha ${ }^{-1}$ ) -5.009 (TL / ha-1), while the compensation amount was estimated to be 17.191 ( $\mathrm{TL} / \mathrm{ha}^{-1}$ ) -9.257 (TL / ha ${ }^{-1}$ ).In case of occurrence of the risk of fire, farmer $0023\left(\mathrm{TL} / \mathrm{ha}^{-1}\right)$ premium pay $0.991\left(\mathrm{TL} / \mathrm{ha}^{-1}\right)$, while compensation expectations, while insurance companies in 0359 (TL / $\mathrm{ha}^{-1}$ ) premium $0707\left(\mathrm{TL} / \mathrm{ha}^{-1}\right.$ ) to pay compensation. Natural risk factors that could not be addressed in the statistical model were collected under the name of other risks and included in the analysis.In case of other natural risks, the premium prices of the farmer and the insurance are $17.191\left(\mathrm{TL} / \mathrm{ha}^{-1}\right)-26.420\left(\mathrm{TL} / \mathrm{ha}^{-1}\right)$, while the compensation amount is $93.877\left(\mathrm{TL} / \mathrm{ha}^{-1}\right)$ 45.320 (TL / ha ${ }^{-1}$ )(Table 5).

In case of occurrence of all natural risks, the farmer pays 20.831 (TL / ha-1) premium and waits for 122.344 (TL / ha-1) compensation, while insurance companies compensate 59.009 (TL / ha-1) premium 84.018 (TL / ha-1). It was estimated that they paid (Table 5).Since half of the premium amount of insurance companies is supported by the state, the premium amount paid by the farmer is 29.505 (TL / ha1).It has been determined that the premium amount determined by the insurance companies is $29.40 \%$ more than the premium amount requested by the farmers. In compensation amounts, it was determined that there is a less than $45.62 \%$ of the compensation amount requested by the farmers.

In general, the risk analysis practices of agricultural products are in the form of farmers' attitudes towards risk, determining the risk sources, measuring the risk encountered and creating risk management strategies that can be applied (Hazneci and Ceyhan 2011; Çetin 2012; Bayramoğlu \& Kaya 2015; Manc1 \&Eren 2017).Risk analysis applications in existing studies are economically based, and yield-based and region-based risk analysis studies are quite limited.In this study, an economic-based, yield-based and region-based risk analysis application is discussed in terms of both manufacturers and insurance companies.

It is understood that the study conducted by Altay \& Keskin (2018) and the results of our study are partially in agreement. There may be parts of this study that are not compatible with the literature, the main reason for this may be the different levels of climate factors, natural risks and the different wheat yield of the district due to the different district.

\section{Conclusions}

In this study conducted to determine the natural risks in wheat cultivation in the Hadim district of Kon- ya, a new risk analysis method has been introduced, and the minimum and maximum risk ranges and premiums and compensation amounts have been determined in terms of farmers and insurance.

The most difficult part in risk analysis applications is the stage of determining the impact of risks. The newly established agricultural risk database in our country creates a huge disadvantage for farmers and insurance companies.Achieving overcoming this disadvantage with qualitative (subjective) methods is a very risky situation. Therefore, quantitative methods should be preferred in solving the problem. With the help of satellite image processing methods (NDVI), which has been developing in recent years, the risk (s) effects can be estimated by processing the images of the risk (s) when they occur, and correlating them with efficiency.In this way, a risk database can be created by accessing satellite images and efficiency information in the past.

Also, Agroshell, Apes, Cropsyst, Daisy, Dssat, Fasset, Hermes, Stics, Wofost etc. In addition to modules, making yield estimates by using satellite images will support healthier and more accurate evaluations in terms of farmers and insurance (Palosuo, 2011; Altay\& Keskin 2018).

These problems are eliminated by both the creation of a database and the widespread use of agricultural technologies in developed countries (Uysal, 2005).In addition, considering the advances in geographic information systems and meteorology, it is expected to reduce the yield loss by developing early warning systems suitable for the characteristics of each region.In this context, it is necessary to provide a more qualified risk assessment opportunity by revealing a new risk analysis method.

Although the agricultural insurance pool provides both premium support and policy support to farmers, it sometimes thinks that the producers cannot cover the risks as they expect, as a result of the private insurance companies' desire to keep their profit rates high.

Farmers want to insure all possible risks by paying the least insurance premium. When considered in terms of farmers, it is clear that there are differences in terms of both climatic conditions and the attitudes of farmers engaged in wheat growing against risk.For this reason, the farmer minimum risk amount of the linear models formed was evaluated as the premium and the maximum amount as the amount of compensation.

Determining the minimum and maximum points within the framework of the linear programming logic did not provide a confidence interval for farmers and insurance companies. It may be a better approach that both stakeholders meet at the midpoint and not burden each other economically.

\section{Acknowledgements}

This study is a part of $\mathrm{PhD}$ thesis entitled corresponding author. The authors would like to thank 
Prof. Dr. Ensar BAȘPINAR, Ankara University, Faculty of Agriculture, Department of Animal Science, for all supports and helps.

\section{References}

Akçaöz H, Özkan B, Karadeniz CF, Fert C (2006). Risk Sources and Risk Strategies in Agricultural Production: A Case of Antalya Province, Turkey. Mediterranean Agricultural Sciences, 19(1), 89-97.

Altay Y, Keskin İ (2018). Determination of Factors Affecting Wheat Production in Altınekin District by Risk Analysis. Selcuk Journal of Agriculture and Food Sciences, 32(3), 496-501.

Altay Y (2019). Agricultural Products Utilization of Risk Analysis Techniques. Selçuk University, Graduate School of Natural and Applied Sciences Department of Animal Science PhD. Thesis, Konya.

Anonymous (2018). https://tr.wikipedia.org/wiki/Hadim. (Date of access: 24.09.2018).

Anonymous (2018a). https://www.mgm.gov.tr. (Date of access: 25.09.2018).

Anonymous (2019). https://web.tarsim.gov.tr/havuz. (Date of access: 04.01.2019).

Apaydin A (1996). Optimization. Anadolu University Faculty of Science Revolving Fund Management Publications, Eskisehir

Bayramoğlu Z, Kaya S, Karakayacı Z (2015). Risk Sources and Risk Strategies in Agricultural Production: A Case of Çumra. Selcuk Journal of Agriculture and Food Sciences, 27(1), 46-54.

Binici T, Koç AA, Zulauf CR, Bayaner A (2003). Risk Attitudes of Farmers in Terms of Risk Aversion: A Case Study of Lower Seyhan PlainFarmers in Adana Province, Turkey. Turkish Journal of Agriculture \&Forestry, 27(5): 305-312.

Cangi SÖ, Oruç E (2017). Approaches to Agricultural Insurance Applications of Farmers Producing Vine Leaves: The Sample of Tokat Province, Turkish Journal of Agriculture-Food Science and Technology, 5 (12), 1640-1650.

Çetin İ (2012).A research on analyzing risk of dry onion growing farms and determining optimum farm organizations under risk in Amasya province. Gaziosmanpaşa University, Graduate School of Natural and Applied Sciences Department of Agricultural EconomicsPhD. Thesis, Tokat.

Çiftçi T (2014). Government Support of Agrıcultural Insurance and System of Agricultural Insurance Pool. Ankara Barosu Dergisi, (4) 525-540.

Çukur F, Saner G (2008). Measurement of risk and strategies against to risk on apricot production in Malatya province. Journal of Agriculture Faculty of Ege University,46 (1): 33-42.
Erdoğan F, Bayramoğlu Z (2017). Risk Analysis by Finney-Kinne Method in Agricultural Enterprices. TEAD, 3(2): 19-28.

Ertan A, Gök M (2012). Analysıs of The Effectıve Factors of Eğirdir Agrıcultural Producers' Decisıon Process on Having an Agricultural Insurance. $O D U$ Journal of Social Sciences Research, 3(5):66-76.

Hazneci E, Ceyhan V (2011). Risk analysis of dairy farms in Merzifon district of Amasya province Mediterranean Agricultural Sciences, 24(2), 109114.

İkikat Tümer E (2004). A study on the attributes of farmers towards agricultural insurance in the villages of Erzurum central district, Atatürk University, Graduate School of Natural and Applied Sciences Department of Agricultural Economics Master Thesis, Erzurum.

İkikat Tümer E (2011a). Determination of Willing to Buy Crop Insurance: The Case of Tokat Province. Atatürk University Journal of Agricultural Faculty, 42(2): 153-157.

İkikat Tümer E (2011b). An analysis on determining the attitudes of the farmers towards risks and possible premium levels for insurance in Erzurum, Erzincan and Bayburt provinces (TRA I region). Atatürk University, Graduate School of Natural and Applied Sciences Department of Agricultural Economics PhD. Thesis, Erzurum.

Sucu M (1996). Linear Programming,. Ankara.

Sümer G, Polat Y (2016). Agricultural Insurance Applications in The World and Tarsim. University Journal of the Faculty of Economics and Administrative Sciences, 18 (1): 236-263.

Karaca A, Karaca A, Gültek A, İntişah AS, Engürülü B, Karlığlu A (2010). Application of agricultural insurance in Turkey.7th Technical Congress of Agricultural Engineering,11-15 January, Ankara, Turkey.

Karahan Uysal Ö, Saner G, Engürülü B, Naseri Z (2014). Implications of Developments in Agricultural Insurance in the world and Turkey,11th Agricultural Economics Congress, 3-5 September, 2: 1042-1050, Samsun, Turkey.

Kızıloğlu R (2017). Determining Factors Affecting Farmers' Agricultural Insurers A Case Study of Akşehir District of Konya Province. Alinteri Journal of Agriculture Sciences, 32(1): 19-26.

Manc1 AR, Eren ME (2017). Risk Analysis of Agricultural Business in Harran Plain. Harran Journal of Agricultural and Food Science, 21(4), 456-465.

Palosuo T, Kersebaum KC, Angulo C, Hlavinka P, Moriondo M, Olesen JE, Trnka M. (2011). Simulation of winter wheat yield and its variability in different climates of Europe: a comparison of eight crop growth models. European Journal of Agronomy, 35(3), 103-114. 
Terin M, Aksoy A (2015). A Research on the Results of Implementation of the State Subsidized Crop Product Insurance: A Case of Mid-East Anatolia Region (TRB), COMU Journal of Agriculture Faculty, 3 (2): 35-43.

Tsikirayi CMR, Makoni E, Matiza J (2013). Analysis of the uptake of agricultural insurance services by the agricultural sector in Zimbabwe, Journal of International Business and Cultural Studies, 7, 1.

Tuik (2018). Crop production statistics, www.tuik.com,(Date of access: 07.11.2018).

Tümer Eİ, Ağır, HB, Uslu Z (2019). Farmers' Crop Insurance Purchase Willingness: The Case of Ilgin
Province in Konya, Kahramanmaraş Sütçü Imam UniversityJournal of Agriculture and Nature, 22(4), 571-576.

Uysal ÖK (2005).A Research on the Attitudes of Farmers Towards Risk: Case of Aegean Region Farmers, Journal of Agriculture Faculty of Ege University, 42 (3), 147-158.

Yapıcı N (2000). The approach of neural networks to fuzzy linear programming, Selçuk University, Graduate School of Natural and Applied Sciences Department of Statistic Master Thesis, Konya. 